\title{
Legal Regulation of Agricultural Taxation
}

\author{
By Inna Kovalchuk ${ }^{1}$, Victoria Melnyk ${ }^{2}$, Tamara Novak ${ }^{3}$, Anna Pakhomova ${ }^{4}$
}

\begin{abstract}
The tendencies of development and peculiarities of agribusiness enterprises activity are established within this research framework. Globalization and liberalization processes have spread rapidly over the past two decades, attracting more and more countries and linking their economies to the world economy. The agro-industrial sector of the economy deserves special attention in international cooperation, characterized by a particular feature, linking geopolitical, economic, social, environmental, sanitary, hygienic norms and rules. Therefore, the experience gained by countries that have long been members of the WTO and have passed certain stages of development and regulation of the tax policy of agribusiness enterprises is worth studying, analyzing, and implementing. The comparative analysis of the results of the realization of the state policy in the field of taxation of agribusiness is carried out during recent years. This research paper analyzes the generalized experience of economically developed countries in the formation of tax policy in the field of agribusiness regulation and identifies opportunities for its application in Ukraine. The study results determine the practical significance of the article, which is determined by the possibility of using the proposed mechanisms to improve the tax policy in the field of agribusiness regulation and identify opportunities for its application in Ukraine.
\end{abstract}

Keywords: agribusiness, taxation, state support for agribusiness, tax policy, agriculture, agricultural production entities

\section{Introduction}

The development of agrarian business is determined by a set of economic, political, social, legal, environmental, and international factors, based on the strategic interests of the country, its investment climate, and its natural and climatic conditions, geographical location, the mentality of the people.

The legislative support and the creation of a favorable investment climate by the state plays great importance for the effective functioning of agricultural production, ie, effective action and improvement of mechanisms of state financial support of agricultural producers in the system of state tax policy, the result of which is the formation of own funds of enterprises through the use of tax benefits, simplified taxation system, application of special value added tax regimes, etc.

Also, the budget support for agricultural development and the need to develop and implement new approaches to attracting financial resources to the industry under targeted

$\mid{ }^{1} \mathrm{PhD}$ in Law, Associate Professor, Head of the Department of Public Law of Bila Tserkva National Agrarian University, Ukraine

${ }^{2} \mathrm{PhD}$ in Law, Senior lecturer in Civil law disciplines Bila Tserkva National Agrarian University, Ukraine

${ }^{3} \mathrm{PhD}$ in Law, Associate Professor in Department of Agricultural, Land and Environmental Law in National University of Life and Environmental Sciences of Ukraine, Ukraine

${ }^{4} \mathrm{PhD}$ in law, Associate Professor, Head of Department of Civil law disciplines of the Bila Tserkva National

Agrarian University, Ukraine 
programs are still relevant.

\section{Review of Literature}

The formation of the budget and tax system in Ukraine takes place in a period of constant transformation of the existing and development of a new regulatory framework for regulating financial and economic relations in agriculture and the agricultural sector of the economy and justifiably remains the subject of current research. The process of changes in the financial and legal mechanism of budget expenditures and special mechanisms of taxation of agricultural producers in particular and the agricultural sector, in general, has been studied in the works of domestic experts in the field of financial law: L.K. Voronova, O.O. Dmytryk, E.S. Dmytrenko, I.B.Zaveriuha, V.V.Kovalenko, A.T. Kovalchuk, V.I. Kurylo, M.P.Kucheriavenko, O.A.Myzuka-Stefancuk, O.P.Orlyuk, O.S.Ryzhenko, and others.

An analysis of the current tax legislation of Ukraine and publications of scientists on this issue showed that a group of scientists believes that in order to stimulate the development of agribusiness in Ukraine, used and previously used preferential direct taxation of organized agricultural formations and a number of special regimes of indirect taxation. Such regimes are applied to stimulate the production and sale of agricultural products through the regime of VAT accumulation, the regime of payment of subsidies, and collection of VAT on the sale of certain agricultural products using a zero tax rate as well as indirect support for livestock production.

\section{Objectives of the Study}

The purpose of this study is: to determine the features of modern financial and legal regulation of budget support and taxation of agricultural businesses; to identify the functional interdependence of agribusiness structural elements in government regulation; to consider a long-term strategy for the development of agribusiness, as well as to outline the prospects for improving the system of state regulation of financial support for agribusiness development by analyzing the regulations and statistical indicators.

\section{Research Methodology}

The theoretical and methodological basis of this research is the dialectical method of cognition, the conceptual provisions set out in the works of domestic and foreign scholars on the legal regulation of tax policy in the field of agribusiness.

To fulfill the tasks, the author used the following main research methods: abstract-logical (for the formation of theoretical ideas about the essence of agribusiness and the peculiarities of taxation in the system of agricultural production); analysis and synthesis (to determine the role of legal regulation of taxation in ensuring the effective development of agribusiness enterprises); abstraction and concretization (to identify the main factors influencing the taxation of agribusiness enterprises); system approach (to develop a scheme of interaction between government and agribusiness enterprises in the formation of tax policy); comparison (for comparative analysis of the tax burden of agribusiness 
enterprises of foreign countries and Ukraine); economic and statistical (to establish the impact of regulatory regulation of taxation on the development of agribusiness in the region).

\section{Need of Study}

Agricultural producers concentrate their financial and material resources, forming a chain of consistent relationships from the supply of raw materials to the agricultural enterprise to the processing and sale of finished products to the final consumer in order to reduce costs or increase income. In world practice, such a system of relationships between enterprises is called agribusiness (Tsiolkovskaya S., 2018).

Structurally, agribusiness is formed by producers of agricultural products directly; suppliers of fuels and lubricants, breeding material; manufacturers of agricultural machinery; contractors (construction, transportation, and logistics, repair, security, food services, etc.); processing enterprises; agricultural traders; enterprises that sell products to the final consumer; intermediaries of different levels, etc. However, it is important to note that the basis of the relationship of these enterprises is the promotion of agricultural products and products of its processing (Tsiolkovskaya S., 2018).

In modern conditions, the success of the national agricultural sector of the economy depends on the construction of integrated systems (production - processing - trade) directly. Therefore, it seems logical to assess the support for the development of agricultural production, including special tax regimes, taking into account the costs of agricultural enterprises associated with the payment of tax payments.

In a crisis of economic development, agricultural enterprises must mobilize all opportunities to ensure the strength of their financial system and maintain a certain level of profitability.

In order to understand the specifics of the income taxation of agricultural producers, it is necessary to understand the basic concept of "agricultural products". The definition of agricultural products is contained in paragraph 14.1.234. Art. 14 of the Tax Code of Ukraine, which provides that agricultural products (agricultural goods) for the purposes of Chapter 1 of Section XIV of the Tax Code of Ukraine: "products/goods falling under the definition of groups 1-24 УKT 3E , if such goods (products) are grown, fattened, caught, collected, manufactured, produced, processed directly by the producer of these goods (products), as well as products of processing and processing of these goods (products), if they were purchased or produced at own or leased capacity (areas) for sale, processing or domestic consumption."

From the scientific point of view, agricultural products are defined as products (crop, livestock, and fish) that are produced (grown) as a result of biological processes of its cultivation, have a natural origin from the earth and (or) from living biological organisms (Urkevich V., 2007).

According to paragraph 1 of Article 32 of the Treaty establishing the European Union, "agricultural products include products of the crop, livestock, fisheries, as well as products of the first stage of processing, directly related to such products" (Petrov V., 2009).

This definition is based on the General Agreement on Customs Tariffs and Trade and is the subject of a broad interpretation (Bytsyura L., 2009). 
The European Court of Justice (ECJU), interpreting the concept of "related products of the first stage of processing", noted that the decisive factor, in this case, is the economic link between the main and processed products, but not the number of successive stages of processing.

However, processed products whose processing cost significantly exceeds basic products' value are not covered by this concept.

The ECJU also ruled that if the concept of agricultural products defines the general principles for the inclusion of these products in the relevant lists, the lists themselves contain precisely defined types of products, applying the Common Customs nomenclature Tariff of the Community. This interpretation has two significant legal consequences:

(a) the condition for determining agricultural production is its indication it in Annex 1 to the Community Treaty or in Regulation 7a;

b) when applying these lists, other positions of the Common Customs Tariff of the Community should be taken into account in accordance with the rules of its use (Burlaka S., 2010).

Hence, in general, the definition of agricultural products in the Ukrainian legislation corresponds to the European Union's legislative practice.

There is a need to clarify the essence of the formation of income of agricultural origin in modern mixed market economies and, on this basis, to ensure an effective system of income generation of farmers in current conditions due to contradictory assessments of the problem of income agricultural enterprises.

The practice has shown that fluctuations in agricultural producers' income are due to many factors: changes in production volumes, prices for products and resources, inflation, interest rates, and exchange rates, tax rates, changes in foreign trade policy, and other conditions. However, the specific instability inherent in agricultural income dynamics is associated with fluctuations in production volumes and prices.

In general, there is the concept of "taxable profit," the amount of which is defined as the difference between gross income and gross expenses of the enterprise - the payer of income tax, reduced by the amount of depreciation. The amount of gross costs and pay for their taxation is determined by organizing tax accounting at the enterprise. After payment of income tax and other taxes, mandatory payments and fees generated by the profit, the company has a net profit, which characterizes the company's overall level of profitability.

The taxation of income tax on agricultural activities has a certain feature. Thus, enterprises whose income for the previous reporting year from the sale of farm products of its own production is more than $50 \%$ of the total income of the enterprise may choose the annual reporting period, which begins on July 1 of the current reporting year and ends on June 30 of the next reporting year.

Agricultural enterprises pay personal income tax on all types of income received by their employees at a rate of $18 \%$. These incomes are also subject to taxation and a single social contribution - $22 \%$ of the accrued amount of income.

Agreeing with the very successful classification of preferential tax regimes for agricultural entities operating in the domestic market of food and other agricultural products, we note that this classification does not consider the tax incentives for exports of domestic agricultural products. 
On the other hand, the tax incentives for the export of agricultural products, which is carried out through the taxation of transactions for the export of these goods at a rate of $0 \%$, is no different from regulation using the tools of the taxation system for the sale of other goods, works and services in Ukraine. Besides, some scholars, given that the export of agricultural raw materials outside of Ukraine, primarily not agricultural enterprises, but grain traders and other entities that resell the industry abroad, do not consider tax exemptions for agricultural exports as a lever to stimulate the activity agricultural enterprises (Berezovsky V., 2009).

The transformation of the socialist system into a capitalist one led to a decrease in agricultural production share in the structure of the gross domestic product. Still, it led to an increase in the profitability and productivity of the agricultural sector. The choice of the agricultural land market development model in these countries gave impetus to rapid socio-economic development.

The main task of state regulation and stimulation of agribusiness development is to implement the state's socio-economic policy in the field of production, distribution, and sale of food in the context of ensuring food security and preserving the ecological balance of the environment.

Peculiarities of the formation of the organizational and economic mechanism of agribusiness development in Ukraine are primarily determined by the nature of the transition period: inflation, the state budget deficit, the lack of a favorable market environment; lack of investment and credit security; decline in production; negative demographic situation; low level of real incomes and insufficient social protection of the population (Grinenko S., 2007).

At the same time, the agro-industrial complex of Ukraine is characterized by certain negative features:

- during all the years of reforming the domestic agro-industrial complex, there is a steady decline in its resource provision, deteriorating conditions of technical renewal, and modernization of material and technical base, especially agricultural production. We are talking about a sharp reduction in the supply with modern tractors, grain and forage harvesting equipment, environmentally friendly tillage machines, and more. Therefore:

- technological requirements, agrotechnical terms of carrying out of these or those types of field works are not observed, their quality and, accordingly, the productivity of the grown-up cultures decreases;

- significantly lags behind modern requirements of technical and technological equipment of processing enterprises, which causes large losses of raw materials, hinders the implementation of its deep processing, expanding the range of goods;

- poorly developed agricultural and technological engineering, the construction industry in rural areas. The resource potential of Ukraine's agro-industrial complex, which before was not in the full sense of the totality and organic unity of technically and technologically related, ecologically balanced and economically balanced production resources, is now continually losing its reproductive capacity (Sytnyk V., 2006).

In the conditions of the crisis, practically all forms of management in the countryside, except for small private peasant farms, proved to be economically incapable of reproducing and renewing the resource potentials of ensuring normal functioning. However, in the latter, there are almost no modern technical and technological means of 
production. The combined effect of negative trends in food production threatens the socalled "systemic separation" of Ukraine from technology, which will further grow into structural and sectoral and institutional incompatibilities and will become an obstacle to Ukraine's integration into the world economic system.

Regional regulation of the effective functioning of agribusiness entities provides for:

- assessment of the investment attractiveness of the regional agro-industrial complex;

- development of targeted regional programs for the development of agribusiness, taking into account the natural resource potential and interests of the territory;

- local financial and budgetary, tax and price regulation;

- social protection of the poor (Bugil S., 2004).

Regulation of agribusiness by market infrastructure entities should provide market conditions for agricultural entrepreneurship, including the formation of markets for production and a wide range of financial instruments for their acquisition, financial and credit support, and information and consulting support agribusiness entities, business risk insurance.

Self-development and self-regulation of business structures of agribusiness are aimed at ensuring their profitable activities and self-financing, through the implementation of such measures as marketing research of food markets, updating the product range; drawing up business plans; establishing vertically integrated connections between the subjects of the food market; business risk assessment.

The purpose of the food market regulation by consumers and public organizations is to protect consumers' rights and ensure the safety of food for their health and life.

It is clear that taxation in agriculture is characterized by certain features associated with implementing certain types of agricultural activities and agricultural production.

The state of taxation of such enterprises also depends on whether the producer of products is considered an agricultural enterprise, and whether the products produced by him are agricultural.

Under Article 1 of the Law of Ukraine "On Stimulating the Development of Agriculture for the Period 2001-2004", it was determined that an agricultural enterprise (including peasant (farming), fishing, and fish farming) is a legal entity whose main activity is the cultivation and processing of agricultural products, the revenue from the sale of which is not less than $50 \%$ of the total revenue (Verkhovna Rada of Ukraine, 2001)..

Accordingly, to the Tax Code of Ukraine, there are two terms used: agricultural enterprise and agricultural producer.

The meaning of the term "agricultural enterprise" was disclosed only in Clause 209 of the Tax Code of Ukraine, from which it can be concluded that this term was used exclusively for VAT purposes.

Thus, under paragraph 209.6 of Article 209 of the Civil Code of Ukraine, an agricultural enterprise was considered to be the main activity of which is the supply of agricultural goods (services) produced by its own or leased fixed assets, as well as tolling conditions, in which the share of agricultural goods services is at least $75 \%$ of the value of all goods/services delivered combined during the previous 12 consecutive reporting tax periods. Article 209 of the Criminal Code of Ukraine expired on January 1, 2017 (Verkhovna Rada of Ukraine, 2017). 
Hence, the analysis of these provisions of the legislation regulates an agricultural producer's legal status as a legal entity or an individual engaged in the production, processing, supply, or sale of farm products.

Legislation of other countries contains similar to the above definition of an enterprise's concept engaged in agricultural activities.

In particular, the definition of "agricultural producer" can be found in European Union law provisions on the structural policy. The concept of "agricultural producer" is not limited to individuals because it also covers legal entities engaged in agricultural production.

European Union legislation goes by expanding the concept of "farmer": a natural or legal person, including a group of natural or legal persons engaged in farming as the main activity; receive income from farming not less than $50 \%$ of their total revenue; the total working time devoted to farming must be at least half of the total working time. Besides, suppose the farmer carries out activities in the field of forestry, tourism, crafts, or activities aimed at protecting the environment. In that case, the amount of income from farming should be at least $25 \%$ of the farmer's total revenue (Khrypko S., 2017).

If we refer to the legislation within the World Trade Organization, the Agreement on Agriculture does not contain a definition of agricultural products' producer.

In accordance with legal research, this is because the Agreement links the receipt of state support in agriculture not so much with the status of the subject but also with agricultural production. The only criterion for classifying an entity as a producer of agricultural products is the production activity referred to as Annex 1 to the Agreement. At the same time, it is not specified whether this type of activity should be the main one, during which period it should be carried out, how much revenue the producer should receive from the sale of agricultural products, it is not even specified whether the agricultural producer should be a commercial organization and a legal entity.

Based on the analysis of paragraph 8 (b) of Annex 2 to the Agreement, the category of land used for agricultural production is not relevant for classification as agricultural producers. However, taking into account that a necessary condition for the production of agricultural products is the use of land, the existence of land rights can also be considered as a sign of a producer of agricultural products from the standpoint of the World Trade Organization.

US agricultural legislation does not establish any amount of agricultural activity for farmers. Thus, by Art. 101 (17) 11 of the Consolidated (Unified) Commercial Code of the United States states that a peasant (farmer) is a person who is permanently engaged in farming, ie, "work on a farm, tillage, work on a dairy farm, ranch, production and growing crops, poultry or livestock, production of poultry or livestock products in a specific processed form" (Report, 2015).

Due to preferential taxation of transactions for the sale of agricultural products outside Ukraine, domestic agricultural formations that export goods abroad do not pay significant amounts of taxes. Besides, even if these products are exported from Ukraine by exporting intermediaries, agricultural producers have a guaranteed sales channel for these products due to their export operations.

Given the above, in our opinion, in the domestic tax levers system for the regulation of agricultural production, it is advisable to single out as a separate direction to stimulate the 
export of domestic agricultural products.

It should be noted that a common feature in the definition of "agricultural enterprise" both in our country and in other countries is that such an enterprise (manufacturer, farm, ranch) is engaged in the production and sale of agricultural products.

Despite a certain reduction in the share of tax support for agricultural entities in their gross output, which has been observed in Ukraine in recent years, it should be noted that its functioning, although not sufficient, but ensures the development of the domestic agricultural sector. Along with this, it should be noted that modern mechanisms of tax support for agricultural enterprises are not without significant shortcomings and contradictions.

The main shortcomings of modern mechanisms of state tax support for agricultural entities are currently the excess of tax benefits to which organized agricultural formations are entitled, over the number of direct budget subsidies they receive, non-compliance with the targeted nature of spending funds remaining in the form of unpaid VAT in the disposal of agricultural producers, as well as control over their intended use, lack of FSP rates due to nominal rates and exemption of its payers from paying payments for the benefit of funding sources for the needs of local communities and reproduction of natural resources, insufficient support for domestic exports of agricultural products.

Globalization and liberalization processes have spread rapidly over the past two decades, attracting more and more countries and linking their economies to the world economy. The agro-industrial sector of the economy deserves special attention in international cooperation, characterized by a particular feature, linking geopolitical, economic, social, environmental, sanitary, hygienic norms and rules. Therefore, the experience gained by countries that have long been members of the W'TO and have passed certain stages of development and regulation of the tax policy of agribusiness enterprises is worth studying, analyzing, and implementing.

Among the most important players with extensive experience in tax regulation of agribusiness should pay attention to the United States, EU countries, Canada, Japan, China, Australia, and more. Despite their many years of practice in international trade, these countries' governments have always been concerned about national food security, the development of agriculture, and agro-industrial producers. Their work aims to stabilize prices for agricultural products, stimulate the export of agribusiness products, protect domestic agricultural producers from cheaper imports, and so on. However, each country has its own stages of introduction of individual institutions in the regulation, control, and support of the agricultural sector and its enterprises, which went from full subsidies and incentives to partial and indirect support of specific activities in crop production or animal husbandry.

Among the formed government actions of highly developed countries in stimulating and supporting the agricultural sector, almost all of them apply protectionist measures to limit excess imports and use incentive methods in the form of subsidies, subsidies, cheap loans, lower tax rates to increase exports of agricultural products and processed products.

In current conditions, the purpose of direct state payments in the agricultural sector in developed European countries is not so much to stimulate production as to solve social problems - maintaining farmers' incomes, providing the population with affordable food, development of rural areas, and agricultural infrastructure, environmental measures. 
Changes in centralized procurement policy have been an essential step towards the liberalization of the CAP. It has been decided that the EU will resort to purchasing surplus products only to protect the market and farmers' incomes when food prices fall to alarmingly low levels. As a result, direct payments to farmers will be limited, and financial resources will be directed to rural development, one of the main focuses of EU policy under the CAP in 2014-2020.

In S. Maystro's opinion, a policy similar to the European Union's CAP would be impossible for Ukraine. After all, the EU spends 2.3 billion euros a year on export subsidies for milk alone. These funds are part of the taxes paid by EU citizens and reach 250 euros per family per year. Against this background, the limit allocated to Ukraine by the total measurement of agricultural support (UAH 3,043 million), ie, about USD 600 million, does not compare with the above figures (Master S., 2017).

Thus, the higher the volume of dairy exports from the EU, the higher its budget costs. And this applies not only to dairy products but also to the entire list of foods.

The solution of agrarian problems in Ukraine can be carried out using people's selforganization in agricultural cooperatives. The uniqueness of the socio-economic nature of cooperative organizations (cooperatives, societies, unions) allowed them in difficult times to become the engine of economic development, the only effective form of social support for both urban and rural populations. This experience, which has become an effective way out of the economic crisis, is over 150 years old using cooperative organizations.

Today, more than 800 million people are members of various types of cooperatives. Half of Singaporeans, one in three residents of Canada and Norway, and one in four residents of the United States and Germany are members of at least one cooperative.

\section{Harmonization of the Tax Legislation of Ukraine and the EU in the Field of Agribusiness Taxation}

The Ukrainian tax system is very similar in appearance to most tax systems in European countries. However, unlike the European Community countries, the tax system of Ukraine is not a tool to increase the competitiveness of the state, does not contribute to the growth of economic activity of economic entities. The current state revenue generation system reflects the imperfections of the transition economy and is mainly fiscal in nature. And the main problem of the Ukrainian tax system is the excessive burden on both businesses and citizens.

An essential factor in ensuring the country's economic stability is the implementation of effective tax policy, which should be aimed at stimulating economic growth and social development. The complexity of business taxation in Ukraine of an organizational nature lies in the need to spend a lot of time on accounting, accrual, and payment of taxes, inspections, reporting, visiting tax authorities. Despite the significant cost of time, domestic entrepreneurs face the complexity and ambiguity of the interpretation of tax legislation (Verkhovna Rada of Ukraine, 2014).

Association with the EU opens vast opportunities for the Ukrainian agro-industrial complex. However, the condition for their full implementation is implementing a considerable set of works on the adaptation of Ukrainian legislation. This primarily aims to eliminate non-tariff barriers to trade, including standardization and metrology, technical 
barriers, accreditation, conformity assessment, and sanitary and phytosanitary measures. The changes should concern the protection of investments and intellectual property rights and other industries.

Apparently, at the time of signing the Association Agreement, no one expected that Ukraine's implementation would be carried out in such difficult economic conditions. In addition to ensuring the fulfillment of its obligations to approximate Ukrainian legislation to the European one, our government must take measures to support business and the population. This means both advisory and financial assistance. After all, the crisis pushes enterprises to realize new prospects, which are silently the EU market.

Ukraine, even in the crisis of the agricultural sector, is an export-oriented agricultural country. Ukrainian agribusiness entities cannot compete with the EU or other developed countries in terms of profitability and investment attractiveness. Improving the competitiveness of agricultural producers and processors of agricultural products in domestic and foreign markets should be a priority for the current government.

Ukraine has committed itself to ensure the gradual adaptation of its legislation to the EU acquis communautaire, closer to harmonization with the relevant EU law and regulatory standards. Our country must gradually adapt its legal framework to European legislation and reform public administration institutions in the field, having declared the priority of European integration, taking into account the principles and approaches adopted in the EU. In particular, the tax system needs to be reformed.

Currently, Ukraine is experiencing growing resistance to promoting its goods and services in foreign markets and is losing ground in the foreign economic sphere.

Under such conditions, the main factor in developing an effective mechanism for the development of national agrarian business, the formation of technologically advanced, environmentally safe, and highly productive production potential is, in our opinion, radical improvement of relations between industry, which provides the agricultural sector with necessary tools and labor and processes agricultural raw materials (products), and directly agriculture as a specific sector of the economy. As the international and domestic experience proves, agrarian business as a special kind of activity develops in the corresponding social environment. For an effective business development mechanism, and in particular agrarian, the authority of entrepreneurial activity must be formed in society. At the same time, it is impossible to succeed without the government and enterprises' joint efforts.

It should be noted that the international experience of agricultural development in recent decades shows the growing role of the state in regulating the agricultural and food markets. Taking into account international experience and the fact that in developed countries, both lease relations and the market of agricultural lands are developing evenly, Ukraine needs to create such areas.

Prices for agricultural land in EU member states reflect significant differences in land quality and location benefits, and land demand.

Most economically developed countries pursue a stimulating agricultural policy, the content of which is to provide various subsidies, subsidies, and benefits to agricultural producers. Its main instruments are compensation payments, payments to compensate for the damage caused by natural disasters, price regulation of the agricultural market, customs, and tariff policy, allocation of funds to develop agricultural infrastructure, agro- 
leasing, and others.

It is difficult to deny that the system of preferential taxation in agriculture in all countries is one of the most important tools of state support for agribusiness.

The primary function of the taxation system in agriculture is not fiscal but stimulating. Its purpose is to formulate favorable conditions for the development of the agricultural sector of the economy and increase its efficiency. Tax revenues from agricultural enterprises in foreign countries are many times less than government spending on agriculture.

Currently, there is no long-term strategy for the development of agribusiness in Ukraine. A significant deterrent to the development of agribusiness is the imperfection of the regulatory framework. It would be unreasonable to say that the agrarian reforms' legal framework is well developed and works flawlessly.

An inevitable imperfection of the regulatory framework creates the preconditions for an arbitrary interpretation of the established procedure for agrarian transformation at various government levels, in regions, districts, directly on the ground. Such order should be interpreted by many in their way, including based on their interests, instead of being perceived, understood, and followed by everyone in the same way. In many cases, this is why the peasants wander to obtain land for the organization of farming, withdrawal of property and land shares from cooperative ownership, and many other similar cases. Illegal actions in this regard on the ground remain, as a rule, uncontrolled and unpunished, which determines their further manifestation, convinces the perpetrators of their omnipotence, complicates the socio-psychological atmosphere in the countryside, develops distrust of the peasants to power and reform.

There is almost no monitoring of the legal framework for agricultural transformation. No state intuitions studies or analyzes how the relevant laws and regulations, the nature of their use, effectiveness, and so on. As a result, such a framework functions mainly on its own, including not as a regulator of agrarian reform, but as a limited annex to it.

The main in the taxation system of agricultural producers abroad is income tax, which is defined as income, fewer production costs, tax-free minimum, and standard discounts.

In the EU, two methods of calculating income tax are used - either based on farm accounting data or the basis of regulatory rather than actual data on producers' activities. For example, in Germany, France, and Italy, where small enterprises dominate the structure of agricultural production, financial reporting is not required, and the regulatory regime of taxation prevails. Taxes are differentiated depending on the volume of production and commodity specialization of farms.

Strengthening the financial condition of farmers is facilitated by established land tax benefits. In some countries, such as Australia and Sweden, all agricultural land is entirely exempt from land tax. The assessment of agricultural land facilitates the reduction of the land tax in some countries not by market value but by agrarian productivity of land, i.e., by the method of land rent capitalization. Simultaneously, the dynamics of current prices for agricultural products do not affect the tax base calculation. For example, in Switzerland, non-agricultural land is valued at market value, and agricultural land is valued at the capitalized rent method. In Finland, the tax base of land tax is formed based on agricultural land's market price, but with a considerable discount.

Besides, to stimulate innovation in the agricultural sector, in addition to accelerated depreciation of means of production, the tax legislation of many countries provides, for 
example, the following preferential tax conditions:

1) the establishment of tax rebates on investment growth;

2) budget compensation for tax payments on investment growth;

3) prolongation of tax payments for the increase of investments for the period of completion of the investment process.

In the legal aspect, miscalculations and mistakes of agrarian reforms are because they are not regulated by law, as it should be, but by imperfect bylaws, compliance with which in practice is not always adequately controlled. Due to incomplete regulation, the inconsistency of complexity, and the importance of various entrepreneurship relations, they cannot properly regulate them. Although in some situations, it is necessary to recognize the expediency of adopting such bylaws to overcome the gaps in the law immediately, only laws can fill the lack of legal regulation. From this point of view, one of the most important tasks of ensuring the rule of law is to provide the relative stability of primarily tax legislation governing business (although strength is challenging to confirm given the ever-changing economic situation and business conditions).

Hence, a significant problem is the shortcomings in the state system of taxation of agricultural enterprises. The main disadvantage and miscalculation are to ignore the specifics of food production. The tax system around the world is built to provide for the creation of conditions for the producer, under which he would be interested in increasing income. In our country, it is directed in the opposite direction. It should be understood that way out of the agro-industrial complex crisis is mainly due to interest, interest. The development of agrarian business cannot be ensured only by appeals, slogans, or even a perfect legal framework. The fundamental idea of a market economy is a free competition. Thus, the proper implementation of these tasks of the organizational and economic mechanism of agribusiness development in Ukraine should be associated primarily with state tax policy, clear delineation of state functions and market self-regulation, and the transition to market methods of agricultural and food policy.

Ukraine has committed itself to ensure the gradual adaptation of its legislation to the EU acquis communautaire, closer to harmonization with the relevant EU law and regulatory standards.

Our country declared the priority of European integration, so it must gradually adapt its legal framework to European legislation and reform public administration institutions in the field, taking into account the principles and approaches adopted in the EU. In particular, the management system of agricultural production and rural areas needs to be reformed in the conditions of decentralization of power, development of local selfgovernment in the countryside, and inter-economic and public self-government in the industry.

Ukraine's foreign trade policy in the agricultural sector, the foundations of which are laid down in the FTA Agreement, meets the W'TO's norms and principles, global requirements for customs and tariff regulation aimed at minimizing agricultural protectionism. But healthy pragmatism, economic goals, and to some extent, conservatism in the issue of optimistic perception of European integration processes in the agricultural sector of the economy shortly level the effectiveness of achieving the objectives of the Agreement, as evidenced by a somewhat biased, inadequate perception of economic reality.

Therefore, it is no coincidence that on January 1, 2017, Ukraine officially joined the 
international trend of "combating tax evasion" and joined the BEPS Association. At least this means that the minimum standard of the BEPS Plan should be introduced into Ukraine's legislation, which includes initiatives aimed at combating tax abuse in the application of tax conventions, increasing the effectiveness of dispute resolution. State Regulation of Economic and Social Development Processes Theory and Practice of Public Administration 4(63)/2018 5 on double taxation agreements, and some others.

The introduction into the national law of rules for the taxation of foreign companies owned and controlled by its residents is an initiative provided for in Step 3 of the BEPS Plan. Today, the tax base's erosion is an urgent problem for Ukraine, so the introduction of tax rules for controlled foreign companies is a priority for our country, but so far, this issue remains unresolved by the Tax Code of Ukraine (Verkhovna Rada of Ukraine, 2010). Quite frequent changes in tax legislation have also become a problematic issue in the field of taxation.

Since the adoption of the Tax Code of Ukraine in 2008, more than 100 amendments, changes, and additions have been made to it. They have often made radical changes in tax legislation, approaches to the calculation, and payment of taxes. Sometimes, the accrual methods, payment of taxes, forms of tax reporting, budget accounts for the payment of taxes, etc. have changed during the period when reporting continues. This leads to situations where the report is not accepted due to a sudden change of form; when some companies have submitted one form, others have to submit a new one. This necessitates the report's re-issuance, the study of new forms of reporting, and stimulates stressful situations for accountants and entrepreneurs. Thus, unstable tax legislation also scares away investors, especially foreign ones (Verkhovna Rada of Ukraine, 2010).

Given the above, it can be stated that in Ukraine, the taxation of agricultural enterprises lies in the level of availability of the primary resource of the industry - agricultural land, while in some other countries, taxable income from the sale of agricultural products and such taxation mechanism does not depend on available agricultural land.

\section{Conclusion}

Hence, the peculiarities of the organizational and economic mechanism formation of the of stable development of agribusiness in Ukraine are primarily due to the peculiarities and main problems of the extended transition period:

- inflation, state budget deficit, lack of favorable market environment;

- lack of investment and credit security;

- decline in production; negative demographic situation;

- low level of real incomes;

- insufficient social protection of the population and, as a result, low purchasing power.

The results of studying the features of the legal regulation of agribusiness taxation provided the development of theoretical and practical recommendations for improving their activity and efficiency, gave grounds for the following conclusions:

1. Liberalization of tax policy is a necessity in the modern system of globalization, it is a sign of readiness for the expanded reproduction of the country's economy or a particular industry, GDP growth, and the formation of a positive balance of export-import balance. 2. In the international community, non-tariff protectionist measures, on the one hand, give 
free access to the market, and on the other - limit it to quotas, licensing, technical barriers, etc. Such actions for Ukraine's economy in general and the agricultural sector, in particular, is significant because the products of domestic agricultural market entities in many respects are still inferior to the products of foreign producers.

3. Analysis of taxation of enterprises of the agro-industrial complex of the regional level in recent years shows the long-term dynamics of its development, which is confirmed by the increase in production and sales. The number of small enterprises, including microenterprises, in agribusiness and related industries has also increased. This indicates the growth of commodity type of agricultural production, self-employment of peasants in entrepreneurial activity.

4. The experience of economically developed countries in the field of taxation of agricultural policy is characterized by long duration, complexity, and multi-stage process. It is the formation of agricultural policy that determines the further actions of agricultural enterprises in international trade. Therefore, the use of the experience of foreign countries can have a positive impact on the rapid formation of their effective agricultural policy and the development of the foreign economic activity.

5. Unfortunately, today, despite the significant changes that are made annually to the Tax Code of Ukraine, the tax system of Ukraine still operates, which does not provide a balanced with the real economy tax burden on businesses, its reform is necessary to immediately stabilize the financial situation, stimulating the processes of economic growth and increasing the investment attractiveness of Ukraine in the international arena as a whole.

6. The current tax system of Ukraine retains a number of significant systemic shortcomings. The roadmap for changing tax mechanisms should be based on ranking the main tax problems, including tax instability, high tax burden, complicated and nontransparent tax administration, which serve as an incentive for business development in Ukraine, the shadow economy, high costs, high smuggling prices goods on the market, uneven tax burden on business, non-refund of VAT, lack of long-term excise taxes on politicians.

7. The most complex is the system of tax administration, characterized by low-quality consulting work; the problem with a return to payers; lack of sufficient electronic services for taxpayers, technically imperfect software; the complexity of tax administration and their declaration; low quality of evidence and inspection reports, negative statistics of administrative complaints in favor of taxpayers; increase the amount of tax debt and write it off to debtors as bad.

8. Taking into account the international experience of applying a differentiated approach to reforming the taxation mechanisms of agricultural enterprises, it can be noted that the taxation system in agriculture of our country needs to be improved, in particular, by introducing taxation mechanisms according to which agricultural land should be taxed. For enterprises engaged in the cultivation of cereals, the object of taxation benefits for goods of agricultural enterprises should be determined by income from the sale of agricultural products.

The use of this proposal will contribute to the even distribution of the tax burden on those enterprises engaged in the production (cultivation) of agricultural products depending on their type of activity, as well as the adaptation of the tax system of our country to the 
requirements of other countries.

9. Based on the analysis of the views expressed in the scientific literature on the maximum size of land plots of private property and the relevant provisions of the Land Code, it becomes clear the need to normalize relations on the maximum concentration of land in individual entities, and related persons are quite obvious.

10. In countries with successful experience in regulating agribusiness taxation, a land market or a market with partial restrictions has been gradually created or fully opened. The transformation of the socialist system into a capitalist one led to a decrease in the share of agricultural production in the structure of the gross domestic product but led to an increase in the profitability and productivity of the agricultural sector. The choice of the agricultural land market development model in these countries gave impetus to the rapid socioeconomic development and growth of the share of agribusiness in the state economy.

11. Analysis of the current tax legislation of Ukraine and publications of scholars on this issue have shown that to stimulate the development of agribusiness in Ukraine, it is necessary to apply preferential direct tax regimes for organized agricultural enterprises actively and a number of special, indirect tax regimes for agricultural enterprises; are used and reduced to stimulate the production and sale of agricultural products through the regime of VAT accumulation, the regime of subsidies and VAT collection on the sale of certain agricultural products using a zero tax rate and indirect support for livestock production.

\section{References}

Berezovsky V. (2009). Tax regulation of the competitiveness of agricultural products. Financial sphere and its role in the growth of competitive advantages of national economies. Irpin. 2009. P. 130-133.

Bugil S. (2004). Organizational features of agro-industrial integration. Visnyk of Lviv. state agrarian. University: Economics of Agriculture. 2004. № 9. P. 496-500.

Burlaka S. (2010). The concept of "agricultural products" in the law of the European Union. Modern land, agricultural, environmental and natural resource law: current issues of theory and practice. Bila Tserkva. 2010. P. 42-44.

Bytsyura L. Features of the definition of agricultural products in the field of common agricultural policy in accordance with the provisions of the Treaty on the Establishment of the European Union. Modern problems of agricultural and natural resource law. Kyiv. 2009. P. 296-298.

Explanatory note to the draft Law of Ukraine "On Amendments to the Tax Code of Ukraine on Tax Reform and Increasing the Investment Attractiveness of Ukraine". Available from: http://search.ligazakon.ua/1 doc2.nsf/link1/GH4S900A.html

Grinenko S. (2007). Logistic direction of development of integrated formations in agribusiness. Economics of agro-industrial complex. 2007. № 9. P. 132-136.

Khrypko S. (2017). General characteristics of farming under the laws of the European Union. Scientific Bulletin of the National University of Life and Environmental Sciences of Ukraine. Kyiv. 2017. Vip. 173. Ch. 2. P. 117-123.

Kovalchuk I. V. (2019). Legal aspects of ensuring the concept of sustainable rural development policy. Regional Policy: Political and Legal Foundations, Urban Planning, Spatial Planning, Architecture. Kiev. 2019. P. 139-143

Kovalchuk I. V. (2019). European experience of regulatory support for the concept of sustainable rural development policy: an ecological aspect. Environmental Policy and EU Law and their Implementation in the Legal System of Ukraine. Kiev. 2019. P. 188-189.

Kovalchuk I. V. (2019). Legal support of the concept of sustainable rural development policy. Agrarian Policy of the European Union: Challenges and Prospects: monograph. Kiev: Center for Educational Literature. 2019. P. 215-226. 
Kovalchuk, I., Melnyk, O., \& Pakhomova, A . (2020). Commercial and Legal Regulation of Advisory Services in the Ukrainian Agrarian Business Prospect Reform. European Journal of Sustainable Development. 9 (3). P. 538. Available from: https://doi.org/10.14207/ejsd.2020.v9n3p538

Master S. (2007). Experience of state regulation of agri-food markets in foreign countries. State building: electron. Science. profession. view. 2007. № 1, Part 1. Available from: http: // www. kbuapa.kharkov.ua/e-book/db/2007-1-1/doc/5/05.pdf

Petrov R. (2009). Law of the European Union. Kyiv. 2009. P. 488-490.

Report on the results of the study of state support of business entities in Ukraine. Available from: http://eupublicprocurement.org.ua/wp-content/uploads/2015/04/STATESUPPORTSTUDY UKR 20.04.2015.pdf

Sytnyk V. (2006). Formation and implementation of state policy for the development of material and technical base of agriculture in Ukraine. Economics of agriculture. 2006. № 2. P. 19-29.

Tsiolkovska S. (2018). Interaction of agribusiness enterprises and public authorities as a way to intensify foreign economic activity. Podolsk Bulletin: agriculture, technology, economics. 2018. Vip. 29. P. 202-210.

Tsiolkovskaya S. (2018). Functions of management and budgeting in foreign economic activity of agribusiness enterprises. Business Inform. 2018. №10. P. 69-74.

Urkevich V. (2007). Agrarian legal relations in Ukraine. Kharkiv. 2007. P. 409-411.

Verkhovna Rada of Ukraine (2003). Commercial Code of Ukraine. Available from: https://zakon.rada.gov.ua/laws/show/436-15

Verkhovna Rada of Ukraine (2003). The Civil code of Ukraine. Available from: https://zakon.rada.gov.ua/laws/show/435-15

Verkhovna Rada of Ukraine (2010). Tax Code of Ukraine. Available from: https://zakon.rada.gov.ua/laws/show/2755-17

Verkhovna Rada of Ukraine (2012). On amendments to some legislative acts of Ukraine concerning the activities of the Ministry of Agrarian Policy and Food of Ukraine, the Ministry of Social Policy of Ukraine, other central executive bodies, whose activities are directed and coordinated through the respective ministers. Available from: https://zakon.rada.gov.ua/laws/show/1807-15

Verkhovna Rada of Ukraine (2014). Association Agreement between the European Union and Ukraine. Available from: https://www.kmu.gov.ua/storage/app/media/uploaded-files/TITLE\%20IV.pdf

Verkhovna Rada of Ukraine (2014). Association Agreement between the European Union and Ukraine. Available from: https://www.kmu.gov.ua/storage/app/media/uploaded-files/TITLE\%20IV.pdf 